\title{
STUDI AWAL PENGGUNAAN DETEKTOR IBA RAZOR DIODA DAN DETEKTOR IONISASI PTW PINPOINT 3D UNTUK PENGUKURAN DOSIMETRI RELATIF
}

\section{Preliminary Study of The Use of IBA Razor Diode Detector and PTW PinPoint 3D Ionization Detector for Relative Dosimetry Measurement}

\author{
Assef Firnando $F^{1}$,Okky Agassy $F^{1}$, Syarifatul Ulya ${ }^{2}$, Pamuji Widodo ${ }^{2}$ \\ ${ }^{1}$ PTKMR BATAN, JI. Lebak Bulus Raya No.49 Jakarta Selatan \\ ${ }^{2}$ Rumah Sakit Kanker Dharmais, Jl. Letjen. S. Parman No.84-86, Jakarta Barat \\ Email : oafirmansyah@gmail.com
}

\begin{abstract}
Abstrak
Hingga tahun 2019 terdapat 44 fasilitas pusat pelayanan radioterapi di seluruh Indonesia. Peningkatan tersebut disertai juga peningkatan fasiltas pendukung yang semakin canggih dan handal. Salah satunya adalah detektor terapi yang digunakan untuk pengukuran dosimetri. Salah satu fungsi dari hasil pengukuran luaran pesawat pemercepat linier medik berupa pengukuran dosis absolut dan dosimetri relatif digunakan untuk memenuhi kebutuhan data jaminan mutu. Dalam makalah ini dibahas mengenai studi awal penggunaan detektor Razor Dioda dan PTW PinPoint 3D pada pengukuran dosimetri relatif. Variasi dosis dilakukan pada rentang 100 - 400 MU, sedangkan untuk laju dosis dari rentang $100-400$ MU/menit. Lapangan radiasi yang digunakan adalah 10 $\mathrm{cm} \times 10 \mathrm{~cm}$ dengan berkas foton 6 dan $10 \mathrm{MV}$ FF. Linieritas bacaan kedua detektor linier terhadap variasi dosis penyinaran yang diberikan. Didapatkan nilai $R^{2}=1$ untuk detektor IBA Razor diode dan $R^{2}=0,9695$ untuk detektor PTW PinPoint 3D. Perbandingan bacaan muatan oleh kedua detektor diketahui berkisar 5\%, hal tersebut sesuai dengan spesifikasi dari kedua detektor. Hasil normalisir bacaan muatan dengan variasi laju dosis penyinaran diketahui masih dalam rentang deviasi pengukuran. Deviasi $-1,09 \%$ didapatkan oleh detektor IBA Razor dioda, dan deviasi -1,59 \% didapatkan oleh detektor PTW PinPoint 3D. Parameter short term stability yang dikarakteristikkan dengan linieritas dosis dan ketergantungan laju dosis yang dimiliki oleh detektor IBA Razor Dioda dan PTW PinPoint 3D mendapatkan kesesuaian yang cukup baik. Hal tersebut membuktikan bahwa kedua detektor mampu untuk melakukan pengukuran dosimetri relatif di lapangan $10 \mathrm{~cm} \times 10 \mathrm{~cm}$ sesuai dengan kondisi standar penyinaran radioterapi.
\end{abstract}

Kata kunci: karakteristik, detektor ionisasi, iba razor, ptw pinpoint 3d

\begin{abstract}
Until 2019 there were 44 radiotherapy service center facilities throughout Indonesia. This increase was accompanied by an increase in supporting facilities that were increasingly sophisticated and reliable. One of them was a radiation therapy detector used for the measurement of dosimetry. One of the functions of the measurement results of medical linear accelerator outputs in the form of measurements of absolute dose and relatively dosimetry used to fulfill the quality assurance. This paper discusses the preliminary study of the use of a PTW PinPoint $3 D$ and Razor Diode detector in relative dosimetry measurements. The dose variations were carried out in the range of $100-400 \mathrm{MU} /$ minute, whereas for the range of dose rates $100-400 \mathrm{MU} / \mathrm{minute}$. The field size used was $10 \mathrm{~cm} \times 10 \mathrm{~cm}$ with photon beams 6 and 10 MV FF. The Linearity of the readings of the two linear detectors against the variation of the irradiation dose given. Obtained value $R^{2}=1$ for the IBA Razor diode detector and $R^{2}=0.965$ for the PTW PinPoint $3 D$. The charge reading ratio by the two detectors was known to be around $5 \%$, according to the specifications of the two detectors. The normalized result of charge readings with variations in the irradiation dose rate was known to be still within the measurement deviation range. A deviation of $-1.09 \%$ was obtained by the IBA Razor diode detector, and a deviation of -1.59 was obtained by a PinPoint $3 D$ PTW detector. The short term stability parameter which was characterized by dose linearity and dose rate dependency possessed by the two detectors gets a good fit. This proves that the two detectors were capable of measuring relative dosimetry in the $10 \mathrm{~cm} \times 10 \mathrm{~cm}$ field by following the standard conditions of radiotherapy.
\end{abstract}

Key Words: characteristic, ionizing detector, iba razor diode, ptw pinpoint $3 d$

\section{PENDAHULUAN}

Perkembangan teknologi radioterapi di Indonesia telah mengalami kemajuan. Pada tahun 2017, sudah terdapat 33 pusat pelayanan radioterapi di seluruh Indonesia
(Hiswara, 2017). Seluruh pusat pelayanan radioterapi tersebut terdiri dari pesawat cobalt60, pesawat pemercepat linier medik linac, dan pesawat tomoterapi. Per tengah tahun 2019, jumlah pusat pelayanan radioterapi telah mencapai 44 pusat pelayanan di seluruh Indonesia. 44 pusat pelayanan tersebut terdiri 
dari 21 unit pesawat cobalt-60, 49 unit pemercepat linier medik linac, 2 unit pesaawt Gamma Knife Radiosurgery dan satu unit pesawat tomoterapi.

Hampir dari seluruh pusat pelayanan radioterapi yang mempunyai pesawat pemercepat linier medik linac menggunakan pesawat linac dengan fitur penyinaran yang menggunakan filter perata berkas [flattening filter (FF)]. Teknologi pesawat pemercepat linier medik linac dengan fitur penyinaran tanpa filter perata berkas [flattening filter free (FFF)] merupakan hal baru di Indonesia. Pesawat pemercepat linier medik linac FFF baru hadir di Indonesia kurang lebih dalam kurun 5 tahun terakhir. Hingga tengah tahun 2019, diketahui sebanyak lima pusat pelayanan radioterapi yang memiliki pesawat pemercepat linier medik linac FFF.

Salah satu rumah sakit yang memiliki pusat pelayanan radioterapi dengan teknologi pesawat pemercepat linier medik linac FFF menggunakan pesawat Elekta Versa HD pabrikan dari Elekta Swedia (Budiantari \& Firmansyah, 2015). Pesawat pemercepat linier medik ini dilengkapi dengan fitur penyinaran berkas foton free flattening filter (FFF) (Papanikolaou \& Stathakis, 2016). Penggunaan fitur FFF ini memungkinkan untuk memberikan penyinaran radiasi ke pasien dengan laju dosis yang lebih besar dan lapangan radiasi kecil (small field). Ukuran lapangan radiasi konvensional adalah berkisar pada $3 \mathrm{~cm} \times 3 \mathrm{~cm}$ hingga $40 \mathrm{~cm} \times 40 \mathrm{~cm}$, dan sedangkan yang disebut lapangan radiasi kecil adalah lapangan radiasi kurang dari $3 \mathrm{~cm} \times 3$ cm (Das, Morales, \& Francescon, 2016). Dalam penggunaan lapangan radiasi kecil ini, penggunaan detektor ukuran kecil diperlukan untuk pengukuran absolut dosis radiasi maupun pengukuran dosimetri relatif, karena hanya detektor dengan ukuran mikro yang mampu untuk melakukan pengukuran.

Kemajuan teknologi detektor ionisasi untuk pengukuran dosimetri lapangan kecil juga berkembang sesuai dengan kebutuhan. Terdapat banyak macam detektor ionisasi lapangan kecil yang telah dijual dipasaran. Beberapa contoh detektor lapangan kecil atau yang sering disebut dengan detektor mikro adalah detektor IBA Razor Dioda fabrikasi IBA Dosimetry dan detektro ionisasi PTW PinPoint 3D fabrikasi PTW Germany.

Guna memenuhi aspek jaminan mutu pelayanan, setiap fasilitas radioterapi melakukan quality control terhadap luaran dari pesawat pemercepat medik linac yang mereka miliki. Quality control tersebut meliputi parameter pengukuran dosis absolut dan pengukuran dosimetri relatif dari luaran pesawat pemercepat medik linac. Saat ini banyak dari fisikawan medis yang menggunakan detektor ionisasi dengan klasifikasi detektor ukuran mini untuk melakukan pengukuran dosimetri relatif. Contoh detektor volume mini yang biasa dipakai adalah IBA CC13 dengan volume 0,13 $\mathrm{cm}^{3}$ dan PTW 31010 semiflex dengan volume $0,125 \mathrm{~cm}^{3}$. Masih jarang ditemui penggunaan detektor mikro untuk pengukuran relatif pada keadaan standar pengukuran dosimetri.

Pada makalah ini dibahas mengenai studi awal pengukuran dosimetri relatif dengan menggunakan detektor ionisasi mikro yaitu PTW PinPoint 3D dan detektor dioda IBA Razor. Studi pada makalah ini mengarah pada pengambilan data berdasarkan keadaan standar pengukuran dosimetri. Pengambilan data dilakukan pada keadaan standar pengukuran, yaitu kedalaman $10 \mathrm{~cm}$ dan lapangan radiasi $10 \mathrm{~cm} \times 10 \mathrm{~cm}$. Tujuan dari studi ini adalah untuk mendapatkan informasi awal mengenai kemampuan pengukuran dari kedua detektor mikro tersebut pada kondisi lapangan penyinaran standar pada berkas foton 6 dan 10 MV FF (Flattening Filter). Berdasarkan informasi dari studi ini, akan dapat digunakan untuk melakukan studi lanjutan mengenai pengukuran relatif parameter dosimetri lainnya dengan menggunakan PTW PinPoint 3D dan detektor dioda IBA Razor.

\section{TINJAUAN PUSTAKA}

Detektor yang digunakan pada studi ini adalah IBA Razor detektor dan detektor ionisasi PTW PinPoint 3D. IBA Razor detektor adalah sebuah detektor dioda keluaran IBA yang dapat mengukur untuk keperluan small field dosimetry, khususnya untuk keperluan dosimetri relatif. Belum direkomendasikan detektor ini untuk kebutuhan pengukuran dosis absolut. Volume aktif dari detektor ini sebesar $0,017 \times 10^{-3} \mathrm{~cm}^{3}$ yang terdiri dari diameter 0,6 $\mathrm{mm}$ dan ketebalan 0,02 $\mathrm{mm}$. Detektor ini menggunakan prinsip kerja sambungan $p-n$ berbahan silicon tanpa menggunakan bias tegangan (0 volt)(IBA Dosimetry, 2014). Detektor IBA Razor ini memiliki stabilitas yang bagus dibanding detektor diode pendahulunya SFD (Liu et al., 2016)

Sedangkan detektor ionisasi PinPoint 3D adalah sebuah detektor ionisasi keluaran PTW yang digunakan untuk pengukuran High Energy Photon Dosimetry. Dikelas detektor untuk pengukuran tingkat terapi, detektor ionisasi PinPoint 3D termasuk detektor yang memiliki volume kecil (PhyisikalischTechnische Werstatten (PTW), 2014b). 
Detektor ini mampu untuk melakukan pengukuran dosis absolut maupun pengukuran dosimetri relatif pada lapangan radiasi yang masih direkomendasikan. Volume sensitif detektor ini sebesar $0,016 \mathrm{~cm}^{3}$. Pengukuran dengan menggunakan detektor ionisasi PTW PinPoint 3D dapat dilakukan pada lapangan radiasi $2 \mathrm{~cm} \times 2 \mathrm{~cm}$ hingga 30 $\mathrm{cm} \times 30 \mathrm{~cm}$, sedangkan IBA Razor detektor dapat mengukur untuk kondisi small field size (kurang dari $3 \mathrm{~cm} \times 3 \mathrm{~cm}$ ).

Kedua detektor tersebut akan dihubungkan dengan elektrometer PTW Unidos Webline T10022/268.

Tabel 1 Karakteristik Detektor yang digunakan

\begin{tabular}{lll}
\hline Parameter & $\begin{array}{l}\text { PTW PinPoint 3D } \\
\text { Tipe 31016 }\end{array}$ & $\begin{array}{l}\text { IBA Razor } \\
\text { Dioda }\end{array}$ \\
\hline $\begin{array}{l}\text { Volume Aktif } \\
\begin{array}{l}\text { Ketebalan } \\
\text { diameter }\end{array}\end{array}$ & $0,016 \mathrm{~cm}^{3}$ & $\begin{array}{l}0,017 \times 10^{-3} \\
\mathrm{~cm}^{3}\end{array}$ \\
$\begin{array}{l}\text { aktif/panjang } \\
\text { Material }\end{array}$ & $1,45 \mathrm{~mm} / 2,9 \mathrm{~mm}$ & $\begin{array}{l}0,6 \mathrm{~mm} / \\
0,02 \mathrm{~mm}\end{array}$ \\
$\begin{array}{l}\text { sensitif } \\
\text { Material }\end{array}$ & Udara & Silikon \\
$\begin{array}{l}\text { Elektroda } \\
\text { Tegangan } \\
\text { Operasi }\end{array}$ & Alumunium & - \\
\hline & \pm 100 Volt -400 & 0 Volt \\
\hline
\end{tabular}

\section{METODE PENELITIAN}

Salah satu parameter untuk mengetahui kemampuan dari sebuah detektor dapat dilihat melalui short term stability dari detektor tersebut. Short term stability dikarakteristikan dengan menggunakan linieritas bacaan dosis dan ketergantungan laju dosis pada sebuah energi penyinaran. Karakterisasi detektor IBA Razor dioda telah dilakukan oleh Giaccomo Regiori dkk pada pesawat linac dengan energi 6 MV-FF, 10 MV-FF,6 MV-FFF,10 MV-FFF (Giacomo Reggiori et al., 2016). Berdasarkan referensi tersebut, pengukuran dilakukan dengan menggunakan pesawat Linac Elekta model Precise TS/1123. Energi penyinaran yang digunakan adalah foton $6 \mathrm{MV}$ dan $10 \mathrm{MV}$ dengan menggunakan flattening filter (FF). Phantom air yang digunakan adalah phantom air buatan PTW Germany berukuran $30 \mathrm{~cm} \mathrm{x}$ $30 \mathrm{~cm} \times 30 \mathrm{~cm}$. Detektor ditempatkan pada kedalaman referensi yaitu $10 \mathrm{~cm}$ dan menggunakan lapangan radiasi standar $10 \mathrm{~cm}$ $x 10 \mathrm{~cm}$. Pesawat Linac Elekta Precise TS/1123 telah dikalibrasi 1 cGy/MU pada $D_{\max }$, $\mathrm{SSD}=100 \mathrm{~cm}$ untuk semua energi penyinaran.

Pengambilan data dilakukan dengan menggunakan variasi dosis dan laju dosis. Variasi dosis dan laju dosis dilakukan pada semua rentang yang tersedia pada pesawat linac Elekta Precise TS/1123. Rentang dosis yang tersedia pada pesawat ini adalah 100 MU, $200 \mathrm{MU}, 300 \mathrm{MU}$, dan $400 \mathrm{MU}$, sedangkan untuk laju dosis tersedia dari rentang $100 \mathrm{MU} /$ menit, $200 \mathrm{MU} /$ menit, 300 $\mathrm{MU} /$ menit, dan $400 \mathrm{MU} /$ menit. Pengukuran dengan variasi dosis penyinaran dilakukan dengan menggunakan laju dosis sebesar 400 $\mathrm{MU} /$ menit, sedangkan pengukuran dengan variasi laju dosis penyinaran dilakukan dengan menggunakan dosis 200 MU. Linieritas bacaan juga dievaluasi pada studi ini.

Set up detektor ionisasi PTW PinPoint 3D dapat dilihat pada gambar 1, sedangkan set up detektor IBA Razor Dioda dapat dilihat pada gambar 2 .

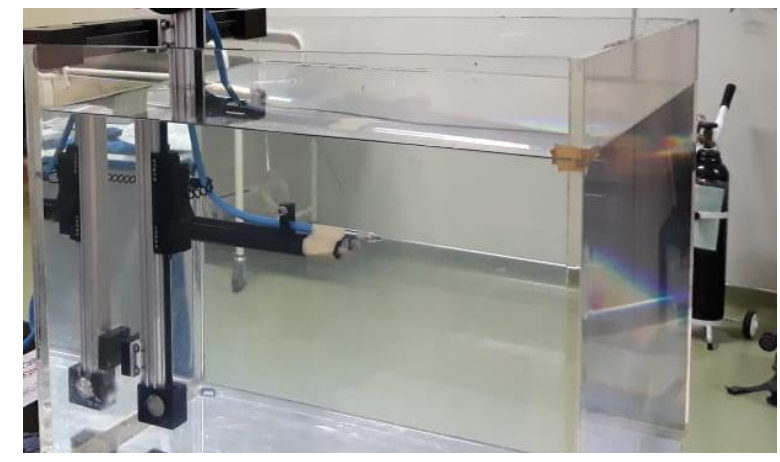

Gambar 1. Penempatan Detektor PTW Pin Point 3D di Pantom Air

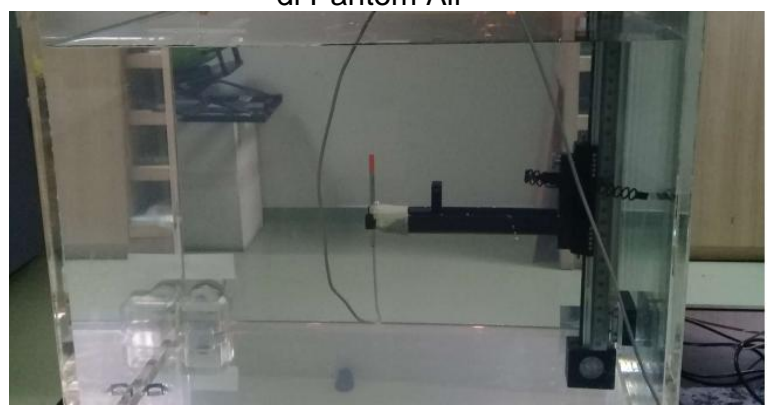

Gambar 2. Penempatan Detektor IBA Razor Dioda di Pantom Air

\section{HASIL DAN PEMBAHASAN}

\section{Linieritas Dosis Bacaan Detektor}

Gambar 3 menunjukkan perbandingan linieritas bacaan dari detektor IBA Razor Dioda dan PTW PinPoint 3D pada variasi dosis penyinaran antara $100 \mathrm{MU}-400 \mathrm{MU}$. Bacaan detektor Razor diketahui linier terhadap perubahan dosis yang diberikan, hal tersebut dibuktikan pada persamaan garis linier dengan nilai $R^{2}=1$. Bacaan detektor PTW PinPoint 3D diketahui juga linier terhadap perubahan dosis yang diberikan, karena nilai $R^{2}$ yang didapatkan mendekati 1 , 
yaitu 0,9695. Kedua detektor Razor dan PinPoint 3D memiliki linieritas bacaan yang bagus.

Hasil ini sama dengan hasil penelitian yang telah dilakukan oleh Giaccomo Regiori dkk(Giacomo Reggiori et al., 2016). Didapatkan Nilai $R^{2}=1$ untuk respon linieritas pada penelitian dengan detektor IBA Razor yang disinari hingga dosis $3000 \mathrm{MU}(\approx 27 \mathrm{~Gy})$. Pengukuran pada studi ini masih berada di dalam rentang pengukuran yang dilakukan oleh Giaccomo Regiori, maka respon linieritas untuk detektor IBA Razor memang baik terhadap perubahan dosis penyinaran.

\section{Perbandingan bacaan detektor}

Rata-rata bacaan detektor Razor pada energi penyinaran $6 \mathrm{MV}$ dengan dosis penyinaran $100 \mathrm{MU}$ didapatkan 2,87 $\mathrm{nC}$, sedangkan pada detektor PinPoint didapatkan rata-rata bacaan $0,27 \mathrm{nC}$. Terdapat perbedaan bacaan diantara detektor Razor dan Pinpoint. Hal tersebut diakibatkan karena respon terhadap radiasi pada kedua detektor ini berbeda. Detektor Razor memiliki respon 4,1 nC/Gy, sedangkan detektor PTW PinPoint 3D memiliki respon $400 \mathrm{pC} / \mathrm{Gy} \quad(0,4 \mathrm{nC} / \mathrm{Gy})$.
Berdasarkan hal tersebut, perbedaan 5\% dari bacaan kedua detektor tersebut telah sesuai dengan spesifikasi respon detektor yang diberikan oleh pabrik. Hal tersebut didukung dengan pesawat linac yang digunakan telah dikalibrasi pada $1 \mathrm{MU}=1 \mathrm{cGy}$, hal ini memenimalisir kesalahan penyinaran yang dilakukan oleh pesawat linac.

Dari tabel 2 dapat diketahui bahwa semakin tinggi dosis penyinaran yang diberikan, semakin tinggi pula charge partikel yang dibaca oleh elektrometer.

Bacaan (nC) dari kedua detektor dikalikan dengan faktor kalibrasi dosis serap air $\left(N_{D W}\right)$ untuk mendapatkan bacaan dosis serap air (mGy). Faktor kalibrasi dosis serap air dari detektor IBA Razor Dioda adalah 243,902 mGy/nC, sedangkan untuk detektor PTW PinPoint 3D adalah $2531 \mathrm{mGy} / \mathrm{nC}$. Dari bacaan dosis tersebut, diketahui rata-rata presentase deviasi antara bacaan detektor IBA Razor dan PTW PinPoint 3D sebesar $3,63 \%$. Data tersebut diperoleh dari perhitungan dengan bacaan dosis detektor PTW PinPoint 3D diasumsikan menjadi referensi pengukuran.

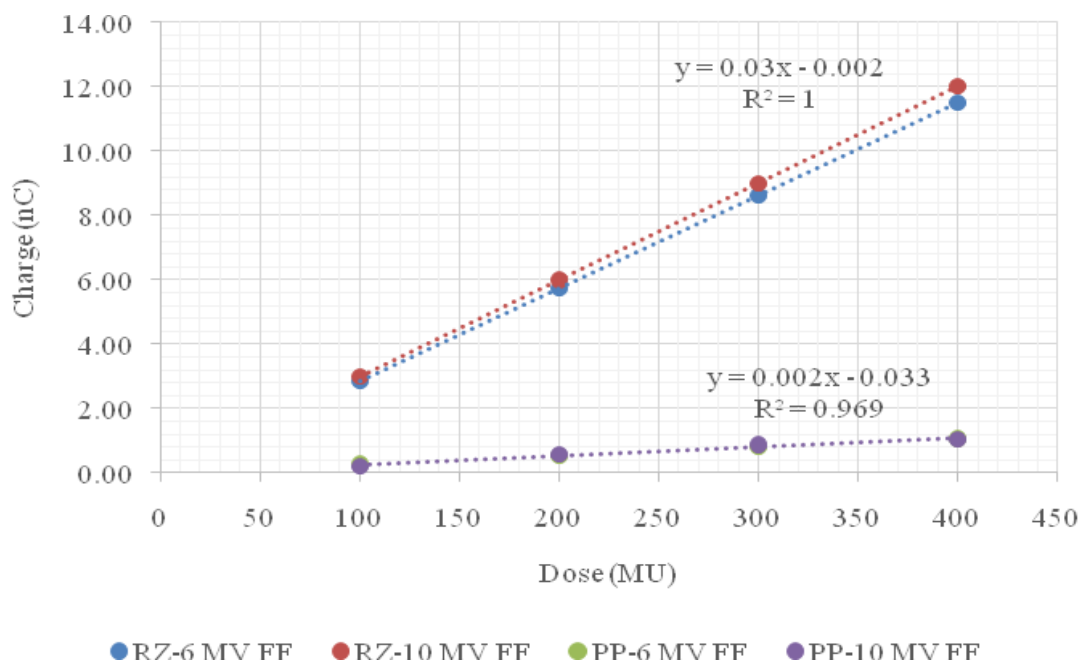

Gambar 3 Grafik linieritas bacaan detektor IBA Razor Dioda dan PTW PinPoint 3D pada variasi dosis penyinaran

Tabel 2 Hasil bacaan detektor Razor dioda dan PinPoint 3D pada variasi dosis penyinaran

\begin{tabular}{|c|c|c|c|c|c|c|c|c|c|}
\hline \multirow{3}{*}{ Dose rate } & \multirow{3}{*}{ Variasi Dosis } & \multicolumn{4}{|c|}{$\mathrm{M}(\mathrm{nC})$} & \multicolumn{4}{|c|}{ Rate elektrometer (pA) } \\
\hline & & \multicolumn{2}{|c|}{$6 \mathrm{MV}$} & \multicolumn{2}{|c|}{$10 \mathrm{MV}$} & \multicolumn{2}{|c|}{$6 \mathrm{MV}$} & \multicolumn{2}{|c|}{$10 \mathrm{MV}$} \\
\hline & & Razor & PinPoint & Razor & PinPoint & Razor & PinPoint & Razor & PinPoint \\
\hline \multirow{4}{*}{$400 \mathrm{MU} /$ menit } & $100 \mathrm{MU}$ & 2,873 & 0,267 & 3,005 & 0,194 & 190,9 & 17,62 & 200,6 & 19,47 \\
\hline & $200 \mathrm{MU}$ & 5,750 & 0,535 & 6,007 & 0,581 & 191,2 & 17,77 & 200,9 & 19,42 \\
\hline & $300 \mathrm{MU}$ & 8,634 & 0,803 & 9,008 & 0,872 & 191,8 & 17,78 & 201,0 & 19,42 \\
\hline & $400 \mathrm{MU}$ & 11,52 & 1,071 & 12,02 & 1,036 & 191,3 & 17,80 & 201,1 & 19,47 \\
\hline
\end{tabular}




\section{Perbandingan ketergantungan laju dosis pada pengukuran}

Dengan menggunakan variasi laju dosis penyinaran pada dosis penyinaran tetap, maka data bacaan charge particle detektor yang didapatkan tidak memiliki perbedaan yang jauh. Ketergantungan laju dosis dari respon detektor IBA Razor dioda dan PTW PinPoint 3D telah dievaluasi pada variasi laju dosis $100 \mathrm{MU} /$ menit hingga $400 \mathrm{MU} /$ menit pada pesawat linac $6 \mathrm{MV}-\mathrm{FF}$ dan $10 \mathrm{MV}-\mathrm{FF}$.
Pengukuran variasi laju dosis dilakukan dengan menggunakan pada dosis $200 \mathrm{MU}(\approx$ 2 Gy). Hasil pengukuran dinormalisir ke bacaan dengan laju dosis $100 \mathrm{MU} /$ menit. Pada penyinaran dengan detektor Razor dengan variasi laju dosis $100 \mathrm{MU} /$ menit, didapatkan rata-rata bacaan arus pada elektrometer sebesar 48,52 pA, sedangkan pada penyinaran dengan laju dosis $400 \mathrm{MU} /$ menit didapatkan rata-rata bacaan arus pada elektrometer sebesar $191,17 \quad \mathrm{pA}$.

Tabel 3 Hasil bacaan detektor Razor dan PinPoint pada variasi laju dosis penyinaran

\begin{tabular}{|c|c|c|c|c|c|c|c|c|c|}
\hline \multirow{3}{*}{ Dosis } & \multirow{3}{*}{ Variasi Dosis rate } & \multicolumn{4}{|c|}{$M(n C)$} & \multicolumn{4}{|c|}{ Rate elektrometer $(\mathrm{pA})$} \\
\hline & & \multicolumn{2}{|c|}{$6 \mathrm{MV}$} & \multicolumn{2}{|c|}{$10 \mathrm{MV}$} & \multicolumn{2}{|c|}{$6 \mathrm{MV}$} & \multicolumn{2}{|c|}{$10 \mathrm{MV}$} \\
\hline & & Razor & PinPoint & Razor & PinPoint & Razor & PinPoint & Razor & PinPoint \\
\hline \multirow{4}{*}{$200 \mathrm{MU}$} & $100 \mathrm{MU} /$ menit & 5,806 & 0,544 & 6,068 & 0,584 & 48,51 & 4,400 & 49,450 & 4,767 \\
\hline & $200 \mathrm{MU} /$ menit & 5,777 & 0,538 & 6,021 & 0,582 & 96,23 & 8,933 & 101,30 & 9,700 \\
\hline & $300 \mathrm{MU} /$ menit & 5,757 & 0,536 & 6,004 & 0,582 & 143,8 & 13,33 & 149,8 & 14,57 \\
\hline & $400 \mathrm{MU} /$ menit & 5,743 & 0,535 & 6,002 & 0,581 & 191,2 & 17,83 & 201,8 & 19,47 \\
\hline
\end{tabular}

Hasil normalisir dari bacaan partikel dapat dilihat pada gambar 4. Grafik menunjukkan trend bacaan yang cenderung menurun terhadap bacaan pada laju dosis 100 $\mathrm{MU} /$ menit. Semakin besar laju dosis yang dipakai, semakin besar deviasi terhadap laju dosis referensi (100 MU/menit).

Deviasi dihitung dengan rumusan matematik hasil nilai bacaan $(Y)$ dikurangi dengan nilai referensi $(X)$, hasil pengurangan tersebut dibagi dengan nilai standar (X). Nilai referensi yang dimaksudkan adalah nilai muatan atau dosis yang didapatkan pada penyinaran di $100 \mathrm{MU}$ atau $100 \mathrm{MU} /$ menit. Pada energi penyinaran $6 \mathrm{MV}$ dengan detektor Razor didapatkan deviasi terbesar hasil normalisasi terhadap laju dosis $100 \mathrm{MU} /$ menit adalah $-1,09 \%$, sedangkan detektor PinPoint 3D mendapatkan deviasi terbesar $-1,56 \%$. Dari hasil tersebut, mengindikasikan bahwa dengan perubahan laju dosis, bacaa dari detektor Razor maupun PinPoint 3D masih dalam rentang yang baik (kurang dari 3,5\% deviasi).

Penggunaan pesawat linac dengan flattening filter masih terbatas pada laju dosis penyinaran hingga $400 \mathrm{MU} /$ menit. Pada beberapa pesawat linac tanpa flattening filter (flattening filter free) laju dosis dapat diketahui mencapai $2000 \mathrm{MU} /$ menit - $2500 \mathrm{MU} /$ menit (G Reggiori et al., 2017; Giacomo Reggiori et al., 2016).

Diketahui karakteristik detektor Razor pada laju dosis $400 \mathrm{MU} /$ menit hingga 2500 $\mathrm{MU} / \mathrm{menit}$ fluktuatif(Giacomo Reggiori et al., 2016). Pada penelitian ini dilakukan pada laju dosis penyinaran pada laju dosis dibawah 400 $\mathrm{MU} /$ menit. Hasil bacaan kedua detektor pada variasi laju dosis menunjukkan grafik yang linier. Semakin tinggi laju dosis yang diberikan, semakin tinggi juga arus yang dibaca oleh elektrometer pada setiap penyinaran. Semakin tinggi laju dosis, maka akan semakin cepat juga waktu yang dibutuhkan untuk mencapai dosis yang ditentukan pada penyinaran. Detektor IBA Razor dan PTW PinPint 3D memiliki short term stability yang bagus pada penyinaran hingga dosis penyinaran $400 \mathrm{MU}$.

Hingga saat ini detektor IBA Razor Dioda belum mampu untuk digunakan sebagai detektor untuk pengukuran dosis absolut. Detektor tersebut sangat cocok untuk digunakan sebagai detektor pengukuran relatif pada lapangan kecil (Azangwe et al., 2014; Tas \& Durmus, 2018). Namun detektor diode ini memiliki kelemahan over response terhadap foton berenergi rendah, dan ketidakseragaman berkas pada sudut angular yang bergantung pada detail konstruksi dan bahan material penyusun detektor. Sedangkan untuk detektor PTW PinPoint 3D merupakan detektor yang termasuk jenis detektor ionisasi mikro, dimana detektor mikro tersebut cocok untuk pengukuran dosis dilapangan kecil. Kelebihan detektor ionisasi mikro dibandingkan dengan detektor dioda adalah kapabilitasnya yang dapat untuk digunakan menentukan dosis dengan energi terbatas (limited energy) dan ketergantungan laju dosis (dose rate dependence) (Agostinelli, Garelli, Piergentili, \& Foppiano, 2008). 


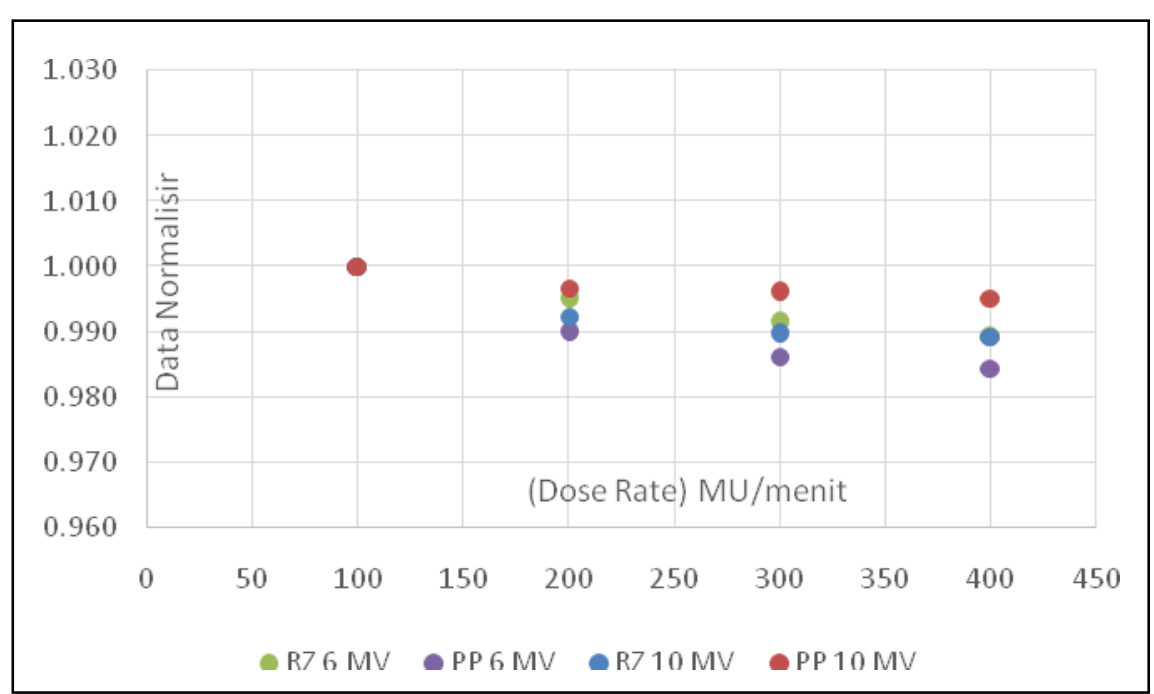

Gambar 4 Normalisir bacaan variasi laju dosis antara detector IBA Razor Dioda and PTW PinPoint 3D

\begin{abstract}
Meskipun penggunaan kedua detektor ini lebih optimal untuk penggunaan pengukuran dosimetri pada lapangan kecil, berdasarkan analisis data diatas detektor ini juga dapat digunakan untuk pengukuran dosimetri relatif pada lapangan standar. Hal tersebut juga didukung bahwa kalibrasi dosis serap air $\left(N_{D W}\right)$ kedua detektor ini masih pada lapangan standar $10 \mathrm{~cm} \times 10 \mathrm{~cm}$. Pada penggunaannya untuk pengukuran dosis serap air dilapangan kecil, detektor razor dioda perlu melalui kalibrasi silang (cross calibration) (Lárraga-Gutiérrez, 2015; Masanga, Tangboonduangjit, Khamfongkhruea, \& Tannanonta, 2016; Phyisikalisch-Technische Werstatten (PTW), 2014a). Berbeda dengan detektor PTW PinPoint 3D yang bisa digunakan langsung untuk pengukuran dosis dilapangan kecil secara langsung dengan menggunakan faktor kalibrasi dosis serap air $\left(N_{D W}\right)$ dari lapangan radiasi standar $10 \mathrm{~cm} \times 10 \mathrm{~cm}$.
\end{abstract}

\section{KESIMPULAN}

Linieritas bacaan kedua detektor linier terhadap variasi dosis penyinaran yang diberikan dengan mendapatkan nilai $R^{2}=1$ untuk detektor detektor IBA Razor diode dan $\mathrm{R}^{2}=0,9695$ untuk detektor PTW PinPoint 3D. Perbandingan bacaan muatan oleh kedua detektor diketahui berkisar 5\%, hal tersebut sudah sesuai dengan spesifikasi dari kedua detektor. Hasil normalisir bacaan muatan dengan variasi laju dosis penyinaran diketahui masih dalam rentang deviasi pengukuran untuk detektor tingkat terapi. Deviasi $-1,09 \%$ didapatkan oleh detektor IBA Razor diode, dan devasi $-1,59 \%$ didapatkan oleh detektor PTW PinPoint 3D.

Berdasarkan data yang telah dianalisis, parameter short term stability yang dikarakteristikkan dengan linieritas dosis dan ketergantungan laju dosis yang dimiliki oleh detektor IBA Razor Dioda dan PTW PinPoint 3D mendapatkan kesesuaian yang cukup baik. Hal tersebut membuktikan bahwa kedua detektor mampu untuk melakukan pengukuran dosimetri relatif di lapangan $10 \mathrm{~cm} \times 10 \mathrm{~cm}$ sesuai dengan kondisi standar penyinaran radioterapi.

Hasil dari makalah ini dapat dijadikan acuan untuk melakukan kegiatan penelitian selanjutnya, yaitu pengukuran dosimetri relatif luaran berkas foton energy tinggi, seperti prosentase dosis di kedalaman (PDD), dan profil dosis dengan menggunakan detektor ionisasi mikro dan detektor dioda.

\section{UCAPAN TERIMAKASIH}

Penulis mengucapkan terima kasih kepada Staf Unit Radioterapi Rumah Sakit Kanker Dharmais atas kerjasamanya sehingga penulisan ini dapat terlaksana.

\section{DAFTAR PUSTAKA}

Agostinelli, S., Garelli, S., Piergentili, M., \& Foppiano, F. (2008). Response to high energy photons of PTW31014 PinPoint ion chamber with a central aluminum electrode Response to high energy photons of PTW31014 PinPoint ion chamber with a central aluminum 
electrode. Medical Physics, 35(2008), 3293-3301.

Azangwe, G., Grochowska, P., Georg, D., Izewska, J., Hopfgartner, J., Andersen, C. E., ... Palmans, H. (2014). Detector to detector corrections: A comprehensive experimental study of detector specific correction factors for beam output measurements for small radiotherapy beams Detector to detector corrections: A comprehensive experimental study of detector speci. Medical Physics, 5541(2010), 072103-1-072103-072116.

Budiantari, C. T., \& Firmansyah, F. (2015). Validasi Hasil Penentuan Dosis Tara Perorangan $H p(10)$ untuk Sumber Radiasi Gamma Cs-137 Di Laboratorium Dosimetri Standar Sekunder (LDSS) PTKMR BATAN. In Prosiding Seminar Nasional Keselamatan Kesehatan dan Lingkungan dan Pengembangan Teknologi Nuklir (pp. 102-106). Jakarta.

Das, I. J., Morales, J., \& Francescon, P. (2016). Small field dosimetry: What have we learnt? In AIP Conference Proceedings (Vol. 1747, pp. 1-10).

Hiswara, E. (2017). Status terkini dan perspektif masa depan radioterapi di indonesia. In Prosiding PPI - PDIPTN (pp. 47-52). Yogyakarta.

IBA Dosimetry. (2014). User's Guide: IBA Razor Detector. Schwarzenbruck.

Lárraga-Gutiérrez, J. M. (2015). Experimental determination of field factors for small radiotherapy beams using the daisy chain correction method. Physics in Medicine and Biology, 60(15), 58135831.

Liu, P. Z. Y., Reggiori, G., Lobefalo, F., Mancosu, P., Tomatis, S., Mckenzie, D. R., \& Suchowerska, N. (2016). Small field correction factors for the IBA Razor. ESTRO 35, 29 April - 3 May 2016, Turin, Italy, 119, S691.

Masanga, W., Tangboonduangjit, P.,
Khamfongkhruea, C., \& Tannanonta, C. (2016). Determination of small field output factors in 6 and $10 \mathrm{MV}$ flattening filter free photon beams using various detectors. Journal of Physics: Conference Series, 694(1).

Papanikolaou, N., \& Stathakis, S. (2016). Commissioning an Elekta Versa HD linear accelerator. Journal of Appied Clinical Medical Physics, 17(1), 179-191.

Pedro Andreo, David T Burns, Klaus Hohlfeld, M Saiful Huq, Tatsuaki Kanai, Fedele Laitano, Vere Smyth, S. V. (2006). IAEA TRS-398: Absorbed Dose Determination in External Beam Radiotherapy: An International Code of Practice for Dosimetry based on Standards of Absorbed Dose to Water (Vol. 2006).

Phyisikalisch-Technische Werstatten (PTW). (2014a). Small Field Dosimetry: Application Guide.

Phyisikalisch-Technische Werstatten (PTW). (2014b). User's Guide: PTW PinPoint 3D Chamber Type 31016.

Reggiori, G, Stravato, A., Mancosu, P., Lobefalo, F., Paganini, L., Zucconi, F., \& Palumbo, V. (2017). Small field characterization of a Nanochamber prototype under flattening filter free photon beams. Physica Medica, 49, 139149.

Reggiori, Giacomo, Mancosu, P., Suchowerska, N., Lobefalo, F., Stravato, A., Tomatis, S., \& Scorsetti, M. (2016). Characterization of a new unshielded diode for small field dosimetry under flattening filter free beams. Physica Medica, 32(2), 408-413.

Tas, B., \& Durmus, I. F. (2018). Small Field Output Factors Comparison between Ion Chambers and Diode Dedectors for Different Photon Energies. In AIP Conference Proceedings (Vol. 170002, pp. 1-5). 
